\title{
The Improvement of Communication and Mathematical Disposition Abilities through Discovery Learning Model in Junior High School
}

\author{
Zinatun Hayati Dina ${ }^{1)}$, M. Ikhsan ${ }^{1)}$, Hajidin $^{1)}$ \\ 1) Syiah Kuala University, Banda Aceh \\ Corresponding author: bayatizinatul@gmail.com
}

\begin{abstract}
The purpose of this study was to determine the improvement of students' mathematical communication and disposition abilities tanght with discovery learning models. This study us quantitative approach with the type of experimental research and the research design us pretest and posttest design type experiments. The sample was chosen randomly from two classes of $7^{\text {th }}$ grade in one of public junior high school in Sigli, Aceh. The research instrument used was mathematical communication ability test and mathematical disposition questionnaire. The data analysis of students' communication and disposition ability was done by two-way ANAVA test at a significant level of 0.05. The results showed that the improvement of students' mathematical communication and disposition skills taught with discovery learning models was better than those tanght with conventional approaches. Furthermore, there was no interaction between discovery learning model and the level of students towards improving communication skills and mathematical dispositions. Therefore, the mathematics teachers can implement discovery learning models in learning to build the next polyhedron. Future researchers should conduct research at other schools in order to improve students' mathematical communication skills in mathematics learning.
\end{abstract}

Keywords: discovery learning model, mathematical communication, mathematical disposition.

Received: 19 $9^{\text {th }}$ September 2018; Revised: 22 ${ }^{\text {nd }}$ January 2019; Accepted: 22 ${ }^{\text {nd }}$ January 2019

\section{Introduction}

Mathematics is one of the subjects learned at every level of education from elementary, middle and high school to college. Mathematics also has an important role in various other disciplines and has a function to develop the human mind. Therefore, students must master mathematics, because mastering mathematics will improve their understanding in other fields. Mathematics can be used as a tool, as a science, as a guide mindset, and also as a form of attitude (Ruseffendi, 2010).

There are several reasons for the need of students to learn mathematics, among others because mathematics is a means of logical and mathematical thinking, a means of developing creativity, and a means of solving problems in everyday life. It is also confirmed by the Ministry of National Education (2013) that one of the graduate competency standards of mathematics subjects for students of basic education units to 
secondary schools. By understanding mathematics, students have the ability to think logically, analytically, systematically, critically and creatively and the ability to cooperate.

In addition to the ability to think logically, systematically, critically and creatively, students must also possess good mathematical communication skills. In accordance with the objectives in the Content Standards for Primary and Secondary Education Units, learning mathematics in schools is communicating ideas with symbols, tables, diagrams, or other media to clarify situation or problem (BNSP, 2013).

The statement about the curriculum above illustrates mathematical communication which is very important in learning mathematics and also an applied science for other sciences. With the existence of mathematical communication, students can clarify their understanding of answering mathematical problems, the communication process helps students develop their ideas and obtain a desired generalization .Mathematical communication in teacher learning must provide opportunities for students to communicate their ideas, such as solving problems or solving table-shaped questions into diagrams, and so on. Therefore, communicating mathematics can train students' abilities.

The indicators of communication skills in mathematics according to NCTM (2000)are 1) the ability to express mathematical ideas through oral and written expression; 2) the ability to use terms, mathematical notation, and their structures to present mathematical ideas; and 3) the ability to present mathematical models to written forms that are well understood and structured. Besides having mathematics communication skills, students also need to have curiosity, and attention, as well as tenacity and confidence in learning mathematics.

This statement is one of the objectives of mathematics education at junior high school level according to 2013 curriculum to develop mathematical disposition. Sumarmo (2013) mentions that the importance of developing mathematical dispositions in learning mathematics is the fact that's students need the ability to appreciate the usefulness of mathematics, as well as curiosity about mathematics and enjoyment in learning mathematics. If this takes place in learning, then unconsciously students will develop a mathematical disposition and they assume that it is an easy lesson. The importance of developing mathematical dispositions is in accordance with what was revealed (Beyers, 2012) that if students have the pleasure of learning mathematics and positive responses to mathematics, difficult math lessons are easy for them, so students are enthusiastic in learning mathematics and mathematical concepts will be attached to the mind they.

Based on the facts in the field, mathematical communication skills and mathematical dispositions of students in schools are still relatively low. The low mathematical communication skills can also be seen from the findings of research conducted by Kristiwan(2012), stating that with students not being trained to express their ideas means low mathematical communication skills. The low mathematical communication skills can also be seen from the findings of research conducted by Dan (2013) stating that students should be trained to express mathematical ideas in mathematical sentences in order to simplify the problems and solutions means low mathematical communication skills. Likewise, students' mathematical dispositions are still low. As the research conducted by Sukamto(2013) shows that students' mathematical dispositions of $61.9 \%$ are in the low category. Students can develop their mathematical dispositions whilestudying several aspects of their mathematical abilities. However, students can lose their confidence if they failto solve the problem. Likewise, students mathematical disposition are still low, as the research conducted by Walker (1999) differences in teaching styles and have detected low self-esteem in students in regard to mathematics, at junior high school students often believe that mathematics is a subject to 
be endured while school and do not see it as a rich, enjoyable and worth while experience.

Based on the results of preliminary observations in SMPN 2 Sigli, low students' participation classroom during learning activities and students' low scores of mathematics tests were also caused by the fact that they lack ability to formulate their own ideas and lack courage to express opinions between friends and teachers in their classrooms. This is caused by learning method that is still largely teacher-centered, in which the students are more focused on receiving information from teachers, which in turn, students' mathematical communication skills are less developed. Students also lack confidence to explore and seek information from other sources, and as a result the students' mathematical communication skills are not developed and they have low mathematics learning outcomes. Therefore, teacher needs to apply a learning model that makes make students more active in learning activities and find their own mathematical concepts.

Discovery learning method is method in which students are given a problem to solve and draw conclusions that match the results based on the desired facts in learning. From this statement, Bruner (Prince \& Felder, 2006) mentions that students can understand themselves and have more freedom in making conclusion that has been learned through observations. There are some goodness of knowledge gained by discovery learning, including how to thoroughly improve students' mathematical communication skills and the ability to think freely (Dahar, 2011). Specifically, learning discovery can train students' cognitive skills to find and solve problems without help or depend on others (be independent). In this learning method, students are asked to analyze and manipulate information, not to just accept it.

One of the learning method in question is learning using discovery learning models. Discovery learning model is a way to develop active students learning by finding their own concepts, investigating their own problems, then the results to be obtained are always in the memory of students (Shadiq, 2009). Discovery learning models encourage students to communicate mathematics by discovering concepts in mathematics that they have never learned before.

Thus, learning mathematics will be more exciting as students can communicate mathematics with thoughts, and fun lessons will also make teacher sable to teach with a slow, calm, and gentle manner. In addition, students will be able to receive the subject matter with pleasure, so that what is conveyed by the teacher will be more accepted quickly and remembered well by students (Djamarah, 2002). In the phases of discovery learning models stimulation and statement problems students are given the opportunity to express mathematical ideas through oral with confidence in communicating ideas, data collection and data processing students are asked to interpret and evaluate mathematical ideas through writing with curiosity and enthusiasm in solving mathematical problems, verification and generalization students are asked to present mathematical models to well-understood and structured forms of writing and reflect their own performance and reasoning. Moejiono (2002) suggests that learning activities with discovery learning model means students can find information themselves to find solutions to problems. Therefore, students can understand what they have learned and learning will be more attached to memory and the knowledge gained will not disappear from their memories.

The results of previous studies have also proven that model discovery learning can improve mathematical communication skills and student disposition. In line with the results of the study of Tukaryanto (2015) using communication techniques using discovery discovery-learning methods. The method used in learning discovery learning in mathematics learning can improve communication skills and learning motivation. Discovery Learning can improve student learning outcomes and skills of the student 
invention compared to using traditional learning models. Alex (2013) in their research found that there are significant differences in learning outcomes between students who use discovery learning and students who do not use discovery learning. Discovery learning has great potential to improve student learning outcomes. With that the right choice if researchers conduct research on discovery learning models in building material in junior high school will be able to improve communication skills and mathematical dispositions and can be used to help students develop their abilities

Based on the description above, the formulation of the problem are:1) Is the improvement of students' mathematical communication skills taught with discovery learning models better than improving students' mathematical communication skills taught by conventional learning?; 2) Is the increase in students 'mathematical dispositions taught by discovery learning models better than that of conventional learning?; 3) Are there relations between discovery learning models and students' level of mathematical communication skills?; 4) Are there relations between discovery learning models and students' level of mathematical dispositions?.

\section{Research methods}

This type of research is categorized into experimental research. The design of this study were implemented in two classes that were chosen randomly. The researchers held different treatments for the two classes, for the experimental learning class by employing discovery learning models, and the control class with conventional learning, then each class was given a pretest to know the initial ability, whether there is a difference between the experimental group and the control group

This research was conducted at one of public junior high school in Sigli. The population in this study were eighth grade students of SMP N 2 Sigli. The sample in this study consisted of two classes to be used as objects of research. The $1^{\text {st }}$ Class is for experimental class and the other one as control class. There were 25 students in the experimental and control class, respectively.

Test results data included results on mathematical communication questions, and student questionnaires included data from students' mathematical disposition scales. The questions that had been made were consulted with the validator to be validated with the aim that there was a match between the question and the indicator of ability to be measured. The validators consisted of two people, namely Magister education mathematics lecturers after the University Syiah Kuala graduate and University Islam Negeri mathematics lecturers. After receiving suggestions and improvements from the validator, then a trial at the school was conducted which aimed to measure the adequacy of time and readability of the questions. Good test questions must go through several stages of assessment including analysis of validity, reliability, differentiation, and level of difficulty.

The data from the communication ability test results from the pretest and posttest scores before the hypothesis testing was first tested, the realized gain. This aimed to see an increase in mathematical communication skills after the treatment was given. Then, the interaction test aimed to see the influence of the learning method given to improve students' communication skills and dispositions. Interaction test was conducted using two-way ANOVA test with the help of SPSS 16.0 with a significant level of $\alpha=0.05$.

\section{Results and Discussion}

The results of the research and discussion were based on the data obtained at each stage of the research. The data to be processed in this study were quantitative data derived from mathematical communication skills tests. Mathematical communication 
skills tests were conducted twice, namely before the application of the learning model and after the application of the learning model. This is done to see the difference in the improvement of students' mathematical communication skills both in classes that use discovery learning models and classes that use conventional learning. Data processing used SPSS 16.0 with a significance level of $\alpha=0.05$.

As many as 50 students involved in this study were divided into two different classes. There were 25 students in class with discovery learning, and there were 25 students in class with conventional learning. The data analyzed in this study included pretest, posttest, and N-Gain scores of students' mathematical communication skills, which were obtained from class with discovery learning model and class with conventional learning. Pretest was conducted in both classes to determine students' abilities before treatment, while posttest was given after treatment. This aimed to see the difference in the improvement of students' mathematical communication skills after treatment was given. More detailed data was presented in the appendix with descriptive details of the pretest, posttest, and N-Gain scores of the two classes presented in the following table:

Table 1. Description of Mathematical Communication Capabilities

\begin{tabular}{llllllll}
\hline Class & \multirow{2}{*}{$\mathbf{N}$} & Test & Min & Max & $\bar{x}$ & SD & Variance \\
\hline \multirow{3}{*}{ Experiment } & \multirow{2}{*}{25} & Pretest & 55 & 87.50 & 67.50 & 8.5 & 72.4 \\
& & Posttest & 70 & 95 & 84.3 & 8.15 & 66.4 \\
& N-gain & 0.076 & 0.88 & 0.49 & 0.25 & 0.064 \\
control & & Pretest & 50 & 77.50 & 63.20 & 7.2 & 62.5 \\
& \multirow{2}{*}{25} & Posttest & 57.50 & 95 & 80.6 & 7.9 & 62.6 \\
& & N-gain & 0.066 & 0.85 & 0.46 & 0.2 & 0.045 \\
\hline
\end{tabular}

The results of the average pretest score of communication skills have a difference of 4.10 , as seen in the maximum value of pretest scores mathematical communication skills obtained discovery learning which showed a value of 87.50 , while in the class that received conventional learning showed a value of 77.50. Therefore, the average score on pretest scores and $\mathrm{N}$-gain increase in mathematical communication skills to obtain discovery learning was higher than conventional learning.

The disposition questionnaire that had been obtained from the data analyzed in this study included pretest, posttest, and N-Gain scores of students' mathematics dispositions who received discovery learning model learning and class students who obtained conventional learning. Pretest was carried out in both classes to determine students' mathematical disposition before treatment, while posttest was given after treatment. This aimed to see the difference in the increase of students' mathematical dispositions after the treatment was given. More detailed data was presented in the appendix with descriptive details of the pretest, posttest, and N-Gain scores of the two classes presented in the Table 2 as follows. 
Table 2. Description of Student Mathematical Disposition

\begin{tabular}{lllllrll}
\hline Class & \multirow{2}{*}{ Nest } & Min & Max & $\bar{x}$ & SD & Variance \\
\hline \multirow{3}{*}{ Experiment } & & Pretest & 72.40 & 99.20 & 86.06 & 6.99 & 48.92 \\
& 25 & Posttest & 79.60 & 99.96 & 93.71 & 5.73 & 32.85 \\
& & N-gain & 0.03 & 1.00 & 0.53 & 0.30 & 0.093 \\
control & & Pretest & 57.56 & 87.20 & 78.11 & 6.48 & 42.01 \\
& \multirow{2}{*}{25} & Posttest & 78.40 & 98.80 & 86.10 & 5.17 & 26.80 \\
& & N-gain & 0.01 & 0.96 & 0.34 & 0.22 & 0.050 \\
\hline
\end{tabular}

The results of the average pretest score of the mathematics disposition of students had a difference of 7.95 , as seen in the maximum value of the pretest score of students' mathematical disposition with discovery learning which showed a value of 86.06 , while in the class with conventional learning showed a value of 78.11. The mean scores on pretest scores and N-gain of students' mathematical dispositions showed that thein crease of mathematical dispositions with discovery learning was higher than that of conventional learning.

Hypothesis testing was done using the Independent Samples Test on SPSS16.0 by using a significance level of $\alpha=0.05$. The test criteria were: Reject H0 if asymp. Sig $<\alpha$. The test results can be seen with the details of the test results shown in the following table:

Table 3. Test Results of Mean Difference of N-Gain Mathematical Communication Capability

\begin{tabular}{ll}
\hline $\mathbf{t}$ count & Sig (2-tailed) \\
\hline 1.046 & 0.048 \\
\hline
\end{tabular}

The first hypothesis was obtained by $\mathrm{N}$-gain mathematical communication ability with $\mathrm{t}=1.046$ and Sig. (2-tailed) $=0.048$. Since the research conducted a one-sided $(1-$ tailed) hypothesis test, then the sig value. (2-tailed) must be divided into two values Sig. $(1$-tailed $)=0.024$. Because the value of Sig. (1-tailed) $<$ level of significance $(\alpha=0.05)$, then Ho was rejected. Thus, it can be concluded that the improvement of students' mathematical communication skills with discovery learning models was better than students with conventional approaches.

Furthermore, the hypothesis that would be proven was the fact that the increase in students' mathematical dispositions taught with discovery learning models would be better than students taught with conventional approaches.

The test used the Independent Samples Test on SPSS 16.0 using a significance level of $\alpha=0.05$. The test criteria were to reject H0 if the Sig. $<\alpha$. Test results can be seen in the appendix with details of the test results shown in the following Table:

Table 4. Test Results of the Difference in the Average N-Gain of Mathematical Disposition

\begin{tabular}{ll}
$\mathbf{t}$ count & Sig (2-tailed) \\
\hline 2,525 & 0,015 \\
\hline
\end{tabular}


The second hypothesis analysis obtained $\mathrm{N}$-gain mathematical disposition with a value of $\mathrm{t}=2.525 \mathrm{Sig}$. (2-tailed) $=0.015$. Since the research conducted a one-sided (1tailed) hypothesis test, then the sig value. (2-tailed) must be divided into two values Sig. $(1$-tailed $)=0.0075$. Because the value of Sig. $(1$-tailed $)<$ significance level $(\alpha=0.05)$, then Ho is rejected. Therefore, it can be concluded that the increase in students' mathematical dispositions with discovery learning models was better than students with conventional approaches.

Then the hypothesis to see the interaction between the learning model and the level of students on mathematical communication skills was performed by testing using Univariate analysis (Two Way Annova) in SPSS 20.0 with a significance level of $\alpha=0.05$. The testing criteria were: Reject H0 if Asymp.Sig $<\alpha$. The test results can be seen with the details of the test results shown in the following table:

Table 5. Analysis of the Correlation between Learning Models and Student Levels on Mathematical Communication Ability

\begin{tabular}{lllllll}
\hline Source & $\begin{array}{l}\text { Type } \\
\text { Sum } \\
\text { Squares }\end{array}$ & $\begin{array}{c}\text { III } \\
\text { of }\end{array}$ & $\begin{array}{l}\text { df } \\
\text { Square }\end{array}$ & $\begin{array}{l}\text { Mean } \\
\text { Square }\end{array}$ & fig. \\
\hline Class & .001 & 1 & .001 & .199 & .658 \\
Subgroup & 2.134 & 2 & 1.067 & 152.517 & .000 \\
Class * subgroup & .020 & 2 & .010 & 1.417 & .253 \\
Error & .308 & 44 & .007 & & \\
Total & 14.085 & 50 & & & \\
Corrected Total & 2.652 & 49 & & & \\
\hline
\end{tabular}

The analysis of the third hypothesis through two-way ANAVA calculations obtained from the sig value., which was obtained from the experimental class was0.253. This value was greater than the level of significance that had been set, which was 0.05. Therefore, based on the testing criteria, $\mathrm{H} 0$ was accepted or in other words H1 was rejected. This meant that there was no correlation between discovery learning models and students' level of mathematical communication skills.

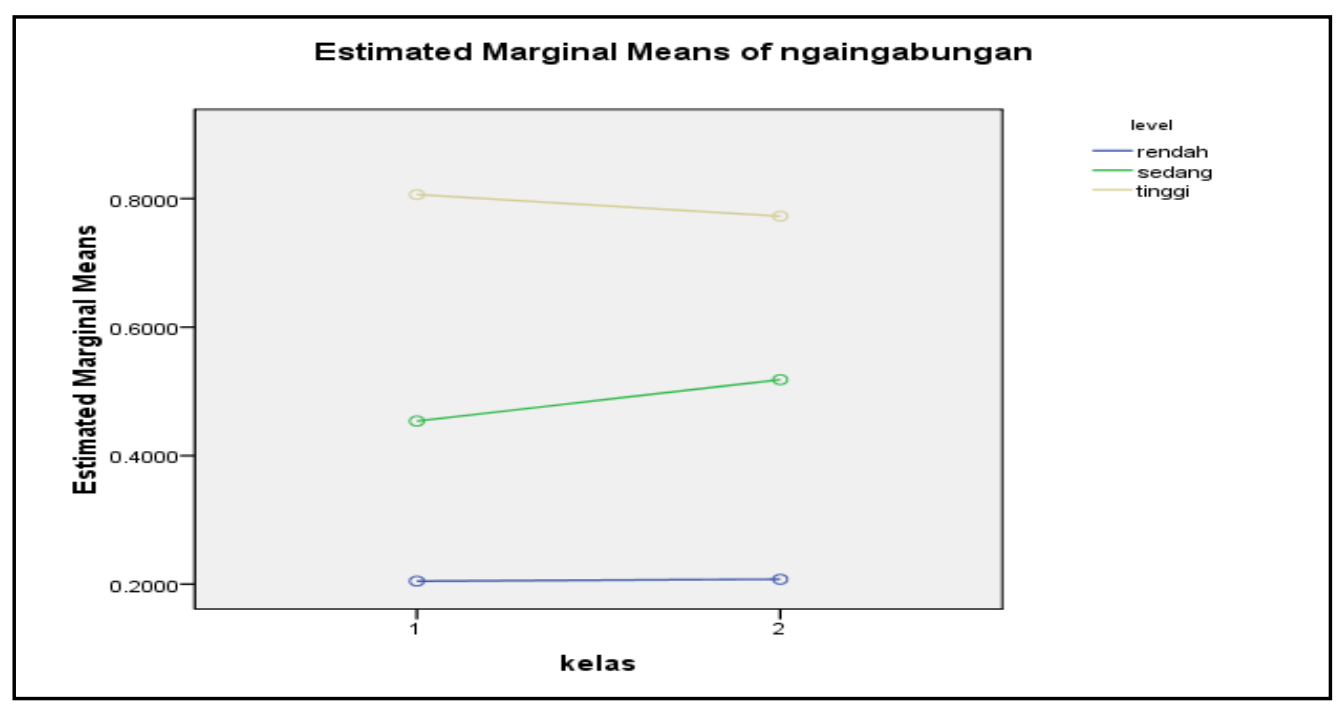

Figure 3. Correlation between Learning Model and Student Level in Mathematical Communication Ability 
Based on Figure 3, it can be seen that the improvement result of students' mathematical communication skills between high and low levels were not much different. It can be concluded that there was no correlation between the learning model and the level of students on improving mathematical communication skills. The increasing in students' mathematical communication skills purely influenced by the learning model. In a sense, discovery learning models can be applied to all levels of students in an effort to improve students' mathematical communication skills.

Furthermore, the hypothesis was tested using Univariate analysis (Two Way Annova) in SPSS 20.0 with a significance level of $\alpha=0.05$. The testing criteria were: Reject H0 if Asymp.Sig $<\alpha$. The test results can be seen with the details of the test results shown in the following table:

Table 6. Correlation Analysis between Learning Models with Student Levels on Student Mathematical Disposition

\begin{tabular}{|c|c|c|c|c|c|}
\hline Source & $\begin{array}{l}\text { Type } \\
\text { Sum } \\
\text { Squares }\end{array}$ & $\begin{array}{c}\text { III } \\
\text { of }\end{array}$ & $\begin{array}{l}\text { Mean } \\
\text { Square }\end{array}$ & f & Sig. \\
\hline Class & .009 & 1 & .009 & .920 & .343 \\
\hline Subgroup & 2.112 & 2 & 1.056 & 104.517 & .000 \\
\hline Class * subgroup & .011 & 2 & .006 & .560 & .575 \\
\hline Error & .444 & 44 & .007 & & \\
\hline Total & 13.525 & 50 & & & \\
\hline Corrected Total & 3.888 & 49 & & & \\
\hline
\end{tabular}

The fourth hypothesis analysis, which was obtained by two-way ANAVA calculation seen from the significant value, obtained 0.575 and this value was greater than the significant level that had been determined, which was 0.05 . Therefore, based on the testing criteria, $\mathrm{H} 0$ was accepted or in other words $\mathrm{H} 1$ was rejected. This meant that there was no correlation between discovery learning models and students' level of mathematical dispositions.

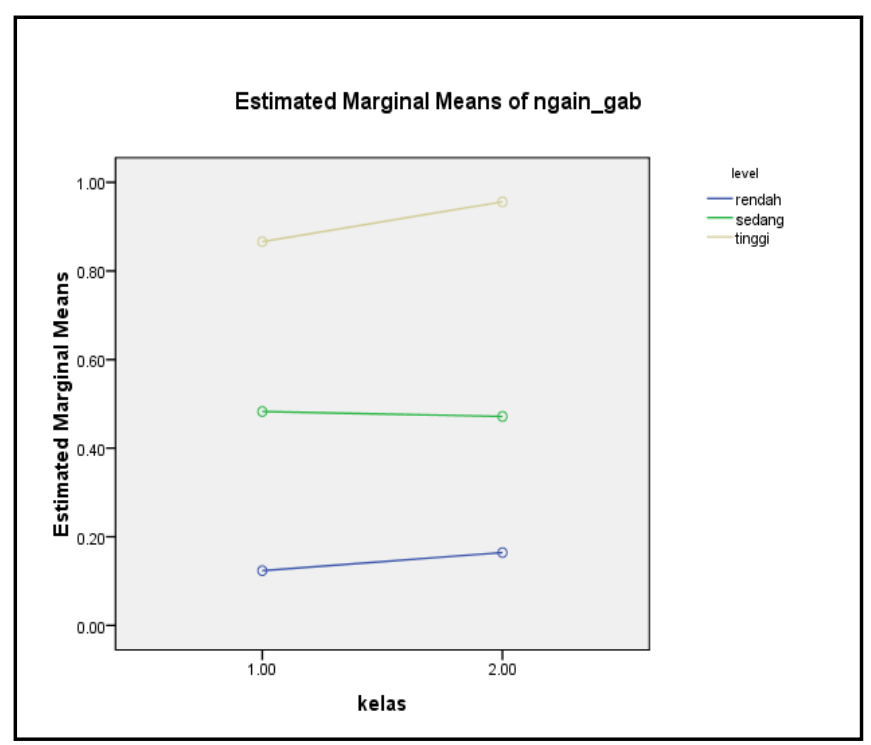

Figure 4. Correlation between Learning Models and Student Levels in Increasing Student Mathematical Disposition 
Based on Figure 4, it can be seen that the increase result in students' mathematical disposition between high and low levels were not much different. It can be concluded that there was no correlation between the learning model and the level of students on increasing mathematical dispositions. This showed that the increase in students' mathematical dispositions was purely influenced by the learning model. In a sense, discovery learning models could be applied to all levels of students as the effort to improve students' mathematical communication skills.

The results of the first hypothesis research concluded that the improvement of students 'mathematical communication skills obtained through discovery learning model was better than the improvement of students' mathematical communication skills obtained through conventional approaches, as reviewed based on the overall students. This was because students who generally showed learning enthusiasm with discovery learning models, they assumed that discovery learning models helped them to easily understand the mathematical material they were learning, and also given the opportunity to express ideas and ideas independently. These results were in accordance with the results of research conducted by Alfieri (2010) that discovery-based methods can improve student learning. Furthermore, the Results were in line with the results of Which (2010) which states that by learning discovery students can learn math concept better where they are involved in the process includes taking a few examples of the mathematics communication, look and test patterns through examples, and generalization their findings with the written word right. So that students can devote their thinking efforts in such tasks and find their own individual learning.

Results of the second hypothesis research concluded that the increase of the students' disposition who experienced learning with discovery learning models were better than students who were taught with conventional models. This was because mathematics learning with the application of discovery learning models made students find out and convey what they know well and also because new things that coordinate students in small groups. Therefore, learning becomes fun, and students were also given the opportunity and encouraged to dare to present the results of his work in front of the class, so that students feel confident in the obtained results. These results were in accordance with the results of research conducted by Sudiani (2016) regarding the mathematical disposition of students who obtain discovery learning models better than the mathematical dispositions of students who obtain expository learning. Other studies that are in line with the results of this study are examined by Crick (2014) The final conclusion is that discovery learning model which is assisted by smart sticker can improve mathematical disposition

The research conducted by Tukaryanto (2015) also supported the findings. The improvement of students' communication skills through an integrated scientific approach to discovery learning models concluded that the approach to discovery learning models in learning mathematics can improve communication skills and learning dispositions.

The third hypothesis in this study concluded that there was no correlation between the learning model and the level of students in improving mathematical communication skills. This explained that the improvement of students' mathematical communication skills was purely influenced by the learning model. Thus, discovery learning models could be applied to all students' levels as the effort to improve students' mathematical communication skills. Juanda's (2014) research results revealed that there was no correlation between the learning model and the level of students' ability to improve their mathematical communication skills. The results of other studies from the study Sibuea (2015) there is no interaction between the learning model and students' initial 
mathematical abilities towards improving mathematical communication skills and mathematical dispositions of students

Finally, the fourth hypothesis in the study concluded that there was no correlation between the learning model and the level of students on students' mathematical dispositions. This can also be interpreted that the increase of students' mathematical dispositions was purely influenced by the learning model. Thus, discovery learning model can be applied to all students' levels as the effort to improve students' mathematical dispositions. This research was in line with the results of Choridah's research (2013) that there was no correlation between students' learning and initial mathematical abilities in improving students' mathematical dispositions. In addition, the results of this study are in line with Widyasari (2016) there is no influence of the interaction between the learning approach and the initial mathematical abilities of students' mathematical disposition abilities.

Improvement of communication skills and mathematical disposition of students who get discovery learning is better than students who get conventional learning. Students do not experience difficulties in learning with discovery learning models in solving communication problems. These difficulties in making a mathematical model to solve the questions given about the explanation of the image, checking the truth of a statement in the form of images and compiling images from known data.

Furthermore, this study shows that there was no interaction between the learning model and the level of students on students' communication and mathematical dispositions. This can also be interpreted as an increase in students' mathematical dispositions purely influenced by discovery learning models. Thus, the discovery learning model can be applied to all levels of students in an effort to improve communication skills and mathematical dispositions of students.

\section{Conclusions}

Based on the results of the analysis and discussion described by testing the first hypothesis, it can be concluded that the improvement of students' mathematical communication skills with discovery learning model was better than the improvement of students' mathematical communication skills with conventional learning. The increase of students' mathematical disposition with discovery learning models was better than the increaseof students' mathematical disposition with conventional learning. There was no correlation between the learning model and the grouping of students on the improvement of mathematical communication skills. There was no correlation between the learning model and the grouping of students on improving students' mathematical dispositions.

The suggestions based on the results of the study indicate that discovery learning improves students' mathematical communication skills better than conventional learning, but the average score obtained still needs to be improved. In order to achieve more optimal results, it is necessary to improve learning activities and also student activity sheets that lead to communication activities and discovery. This research can be a reference to continue to develop students' mathematical communication skills by applying other high-level mathematical communication indicators. Students need to be given more varied and challenging practice questions and require students to give reasons for the problem solving process, as well as time for longer training. Therefore, it can encourage students to achieve good results in mathematical communication and the expected mathematical disposition behavior. 


\section{References}

Alex, A. \& Olubusuyi, F. (2013). Discovery Learning Senior ang School Students Performance in Mathematics in Ejigbo. Journal of Education and Practice Vol 4, No. 12, 2013.

Alfieri, L. (2011). Does Discovery-Based Instruction Enhance Learning?. Journal of Educational Psychology American Psychological Association 103, (1), 1-18.

Beyers, J.E.R. (2012). An Examination of the Relationship Between Prospective Teachers' Dispositions and Achievement in a Mathematics Content Course for Elementary Education Majors. Journal of SAGE Open. International Journal of Business and Social Science, 2(16); 20-32.

BSNP. (2013). Panduan Penyusunan Kurikulum Tingkat Satuan Pendidikan Jenjang Pendidikan Dasar dan Menengah. Jakarta: BNSP

Choridah, D. T. (2013). Peran Pembelajaran Berbasis Masalah untuk Meningkatkan Kemampuan Komunikasi serta Disposisi Matematis Siswa SMA. Jurnal Ilmiah Program Studi Matematika STKIP Siliwangi Bandung Infinity. Vol. 2(2)

Crick, R. D., \& Goldspink, C. (2014). Learner Dispositions, Self-Theories and Student Engagement. British Journal of Educational Studies, 62 (1), 19-35.

Dahar. R.W. (2011).Teori-Teori Belajar dan Pembelajaran. Bandung: Erlangga

Dan S. (2013). The Study On Mathematical Communication Competence and Its Asessesmen in China: The Prelimanary Findings. East Normal University. Proceedings Earcome 6. Innovations and Exemplary Practices in Mathematics Education. 17-22 March 2013

Departemen Pendidikan Nasional (2013). Permendikbud Nomor 81 A Tabun 2013 Tentang Implementasi Kurikulum. Jakarta: Depdiknas.

Djamarah, B., and Aswan, Z. (2002). Strategi Belajar Mengajar. Jakarta: Rineka Cipta Juanda, M. (2014). Peningkatan Kemampuan Pemecahan Masalah dan Komunikasi Matematis Siswa SMP melalui Pembelajaran Means-Ends Analysis (MeA). Jurnal Kreano, vol.5 (2). 2014. Diterbitkan oleh Jurusan Matematika FMIPA UNNES

Kristiwan, Budi. (2012). Meningkatkean Kemampuan Komunikasi Dan Penalaran Matematis Melalui Pembelajaran Inkuiri: Studi Eksperimen pada Siswa SMA Negeri 1Kadipaten Majalengka. S2 thesis, Universitas Pendidikan Indonesia.

National Council of Teachers of Mathematics. (2000). Principles and Standards for Schools Mathematics. Reston Va: NCTM.

Mudjiono \& Djimiati. (2002). Belajar dan Pembelajaran. Jakarta: Rineka Cipta.

Prince, M. J., and Felder, R. M. (2006). Inductive Teaching and Learning Methods: Definitions, Comparisons, and Research Bases. Journal of Engineering Education, 95 (2), 123-138.

Ruseffendi, E.T. (2010). Pengantar Kepada Membantu Guru Mengembangkan Kompetensinya dalam Pengajaran matematika untuk. Meningkatkan CBSA. Bandung: Tarsito

Shadiq, F. (2009). Model-model PembelajaranMatematika SMP. Sleman: Depdiknas

Sibuea, M.F, dkk .(2015). Peningkatan Kemampuan Komunikasi dan Disposisi Matematis Siswa SMK Tamansiswa Sukadamai Kabupaten Asahan melalui Model Pembelajaran Berbasis Masalah. Jurnal Paradikma, 8(3), 70-83.

Sudiani, N. (2016). Implementasi Model Pembelajaran Discovery Learning untuk Meningkatkan Kemampuan Berfikir Kritis dan Kreatif Matematis serta dampaknya terhadap Disposisi Matematis Siswa SMP. Artikel Jurnal Penelitian. Accessed on 16 January 2018, http://jurnalpenelitiannenisudiani.

Sukamto. (2013). Strategi quantum learning dengan pendekatan konstruktivisme untuk meningkatkan disposisi dan penalaran matematis siswa. Jurnal: UNNES Journal of Primary Educational, II (2), 91-98. 
Sumarmo, U. (2013). PendidikanKarakter, Berpikir dan Disposisi Logis, Kritis, dan Kreatif dalam Pembelajaran Matematika. Makalah disajikan dalam perkuliahan evaluasi matematika 2011 Pascasarjana UPI. Unpublished paper.

Tukaryanto. (2015).Peningkatan Kemampuan Komunikasi dan Motivasi Belajar Siswa melalui Pendekatan Saintific Terintegrasi pada Model Pembelajaran Discovery Learning. Jurnal Pendidikan. 7(5),178-189.

Walker, M., \& Chamberlain, M. (1999). A brief overview of the Third International Mathematics and Science Study (TIMSS) including the concept framework for the study, sampling procedures, and a summary of key results for New Zealand. The research bulletin. 10. Wellington: Ministry of Education.

Which, EFY, Liao, CCY, Ching, Y., Chang, T., Chan, TW (2010). The Effectiveness of Inductive Discovery Learning in 1: 1 Mathematics Classroom. Proceedings of the 18th International Conference on Computers in Education

Widyasari, N. dkk. (2016). Meningkatkan Kemampuan Disposisi Matemaika Siswa SMP Melalui Pendekatan Methaporical Thinking. Jurnal Pendidikan Matematika \& Matematika. Fibonacci. 2(2), Desember 2016. 